the scales " physical functioning "( $\mathrm{p}<0.01)$ and" emotional state " ( $\mathrm{p}<0.05)$. When comparing the results of the questionnaire in dynamics in group I in two related samples, statistically significant differences $(p<0.05)$ were revealed in the calculation of indicators of six of the eight scales of the questionnaire: the scales "physical functioning", "role physical functioning", "role emotional functioning", "emotional state", "social functioning", as well as the scales of pain. When comparing the indicators obtained in the survey of parents (guardians) of patients of subgroup II B, a correlation between the indicators of questionnaires "cochlear implant functioning Index" and "auditory integration Scale" on the scales "speech perception in the background noise" $(p=0.02)$ and "communication at school)" $(p=0.001)$ was revealed.

Conclusion. Evaluation of the survey results using GBI and GCBI showed that cochlear implantation has a beneficial effect on the quality of life of patients.

$$
* * *
$$

1. Кузовков В.Е.Современные хирургические подходы к проведению кохлеарной имплантации. Автореф....докт.мед.наук,Санкт-Петербург, 2011: 35

2. Кузнецов А. О. Критические параметры систем слуховой имплантации. Автореф. ...докт.мед.наук, Москва, 2017: 35

3. Тарасова Н.В. Комплексное сопровождение детей после кохлеарной имплантации в центре оториноларингологии. Автореф . ... канд. пед. Наук. Москва, 2010:20

\title{
Rasulova M.A. \\ Provision of dental care to persons with mental disorders
}

Azerbaijan Medical University

(Azerbaijan, Baku)

doi:10.18411/sciencepublic-15-11-2019-09

idsp: sciencepublic-15-11-2019-09

One of the important and unresolved issues in persons with severe mental illness is the provision of specialized dental care to this population, which is often due to their physical and mental state are not able to turn to the right specialists in time, and, despite a comprehensive examination and treatment, do not comply with medical appointments and rules for hygienic care of the oral cavity [1].

Thus, mental diseases and long-term use of tranquilizers, antidepressants, anticonvulsants cause negative changes in the autonomic nervous and endocrine systems, expressed disturbances in metabolic processes [2].

At the same time, the lack of proper hygienic care, violations in the functional state of the organs and tissues of the mouth significantly increase the risk of odontogenic foci of infection [3]. disorders.

The aim of the research is to Assess the dental status of patients with mental

Methods. The study of 220 mentally ill and 208 practically healthy persons was conducted using CPI and CPITN indices to determine the level of prevalence and intensity of caries, periodontal diseases and to identify the need of the examined patients for complex dental treatment. Groups of patients are comparable in age: $n=220$-average age-35,2 $\pm 0,39$; $\mathrm{n}=208$-average age- $34,3 \pm 0,40,(\mathrm{p}=0,1152)$. The functional state of salivary glands and oral fluid was studied. The psycho-emotional status of patients was determined by us before the beginning of dental manipulations by the clinical and psychological method (spielbergerHanin scale of assessment of the level of reactive and personal anxiety, 1970).

Results. In the main group, the number of patients with various forms of caries was $100 \%$, while in the group of mentally healthy persons, the number of such was $91.8 \pm 1.90 \%$ $(\mathrm{p}=0.0001)$. Due to the high intensity of carious disease, especially the number of teeth removed, there was a rather high need for mental patients in dental prosthetics. The highest 
level of intensity of Tartar deposition and deep pathological periodontal pockets was found in the main group. Peaks in salivation decline or hyposalivation were more often diagnosed in patients with mental illness. When assessing the frequency of occurrence of dental anomalies (PCA), deep bite and progenia occupied the highest proportion in both groups in relation to other types of anomalies, but in the main group the frequency of occurrence of cross bite was higher $(\mathrm{p}=0.0151)$. The rate of reactive anxiety during dental interventions in the main group was $50.1 \pm 0.72 \%$, compared to $31.6 \pm 0.57(\mathrm{p}<0.001)$ in the control group. A similar pattern was observed when assessing the level of personal anxiety in the subjects.

The conducted clinical study and the results of the questionnaire show that the values of the high level of reactive anxiety in mentally ill and practically healthy individuals at the stages of treatment are markedly different. Taking into account the fact of the negative influence of somatic pathologies on the functional state of saliva, some of its structural parameters, including fluctuations in the $\mathrm{pH}$ of the oral fluid, were studied. In our studies in the control group, the $\mathrm{pH}$ value was recorded within the normal range. In the main group, the $\mathrm{pH}$ of the oral fluid was lower and there was a pronounced shift in the $\mathrm{pH}$ of saliva to the acidic side- $6.11 \pm 0.030$ versus $7.02 \pm 0.041$ in the control group $(p<0.001)$. Thus, the presence of mental disorders and taking potent drugs leads to serious disturbances in the acid-alkaline balance of the oral cavity and its shift to the acidic side.

Conclusion. The results of the studies indicate a high level of incidence of inflammatory and destructive diseases of periodontal tissues and hard tissues of teeth in the main group of persons with mental disorders. The presence of the studied somatic pathology negatively affects the state of acid-base balance of saliva with its shift to the acidic side-and the frequency of development of dental anomalies. Key words: mental illness, dental caries, periodontitis, saliva, anomalies.

$$
* * *
$$

1. Kumar A., Kardkal A., Debnath S., Lakshminarayan J. Association of periodontal health indicators and major depressive disorder in hospital outpatients The Journal of Indian Society of Periodontology, 2015; 19 (5): $507-511$

2. Nayak S.U., Singh R., Kota K.P. Periodontal Health among Non-Hospitalized Chronic Psychiatric Patients in Mangaluru City-IndiaJClinDiagn Res. 2016 Aug; 10(8): 40-43

3. Nayak SU, Nayak DG, Uppoor AS, Pai KK. Evaluation of cortisol levels in gingival crevicular fluid and saliva in anxious and non-anxious patients with chronic periodontitis. DentResJ. 2013;10:474-81

\section{Salihova K.M. \\ Prevalence of different pathologies in the practice of a family doctor}

Azerbaijan State Institute Of Improvement Of Doctors named after A. Aliyev

(Azerbaijan, Baku)

doi:10.18411/sciencepublic-15-11-2019-10

idsp: sciencepublic-15-11-2019-10

General practitioner (family doctor) - a specialist who has training in related specialties and is able to provide multidisciplinary outpatient care for the most common diseases and emergencies. Ophthalmology is one of the areas of medicine responsible for the prevention, diagnosis and treatment of eye diseases. [1,2]

The incidence of myopia in the Nenets Autonomous district exceeds the average Russian level by 4 times, in the Chukchi Autonomous district-by 2 times, in the republics of Komi, Chuvashia, Altai, Sakha (Yakutia), Udmurtia, Mari El, Bashkortostan, Krasnoyarsk Krai, Kurgan region - by 1.5 times. At the same time, in the Chechen Republic, myopia is detected 2.5 times less often than in Russia as a whole.

The incidence of glaucoma, exceeding the national average by 2 times, was noted in the Ivanovo region, St. Petersburg, 1.5 times - in the Republic of Sakha (Yakutia), Kurgan, Kirov, Omsk regions, Nenets Autonomous district. 